\title{
OPTICAL DATING OF A LATE QUATERNARY SEDIMENT SEQUENCE FROM SOKLI, NORTHERN FINLAND
}

\author{
HELENA ALEXANDERSON ${ }^{1}$, KARI O. ESKOLA ${ }^{2}$ and KARIN F. HELMENS ${ }^{3}$ \\ ${ }^{I}$ Department of Plant and Environmental Sciences, Norwegian University of Life Sciences, \\ P.O. Box 5003, NO-1432 As, Norway \\ ${ }^{2}$ Dating Laboratory, University of Helsinki, \\ P.O. Box 64, 00014 Helsinki, Finland \\ ${ }^{3}$ Department of Physical Geography and Quaternary Geology, Stockholm University, \\ SE-106 91 Stockholm, Sweden
}

\begin{abstract}
Interstadial and non-glacial stadial sediments collected in boreholes from Sokli in northeastern Finland have been dated by optically stimulated luminescence on quartz and feldspar grains. The quartz OSL ages follow stratigraphic order, with one exception, and support the litho- and biostratigraphical correlation with the NW European mainland climate-stratigraphy and the marine oxygen-isotope stages. Feldspar IRSL dates generally overestimate the age, probably due to incomplete bleaching.

The data show that during the last glacial cycle north-eastern Finland was not glaciated until MIS $5 \mathrm{~b}$, around $90 \mathrm{ka}$. Interstadial conditions occurred around $\sim 94 \mathrm{ka}$ (MIS 5c), 744-80 ka (MIS 5a) and 42-54 ka (MIS 3).

The OSL ages have large standard errors mainly due to small sample sizes, relatively poor luminescence characteristics and uncertainties in dose-rate determinations.
\end{abstract}

Keywords: OSL, interglacial-glacial cycle, Fennoscandia, Finland, Weichselian, interstadial.

\section{INTRODUCTION}

A nearly continuous sediment sequence that spans the last interglacial-glacial cycle and the present interglacial (last $\sim 130 \mathrm{ka}$ ) has been recovered from a small sedimentary basin in the Sokli Carbonatite Massif in Finnish Lapland (lat. $67^{\circ} 48^{\prime} \mathrm{N}$, long. $29^{\circ} 18^{\prime} \mathrm{E}$, alt. $220 \mathrm{~m}$; Fig. 1). The sediment sequence is unusually long for Fennoscandia and shows that despite the fact that the Sokli area has been repeatedly glaciated by the Fennoscandian ice sheet during the last glacial, till beds and ice-marginal fluvial sediments as well as lacustrine and fluvial sediments were not eroded. This has allowed for the preservation of a sediment sequence that represents a unique record of Late Quaternary climate variability (Helmens et al., 2000; 2007a; 2007b).

Litho- and biostratigraphic evidence provides an excellent relative chronology for the Sokli basin sediments, encompassing five major climate cycles of Late Quaternary age (Helmens et al., 2000). Absolute age control of the sediment sequence has up till now been mostly based on correlation of this evidence with the NW European mainland climate- and deep-sea oxygen-isotope stratigraphies (Helmens et al., 2000). Only three AMS radiocarbon dates $\left(8->42{ }^{14} \mathrm{C} \mathrm{ka} \mathrm{BP}\right)$ for the upper part of the sediment sequence and four bracketing TL and OSL dates ( $\sim 110 \mathrm{ka}$ above and 150-178 ka below) for the interglacial bed near the base of the sequence were available (Helmens et al., 2000). An improvement of the absolute chronology is therefore vital and the aim of this study is to get additional chronological control of the Sokli sequence. Here we present results from optical dating of sediments deposited in the Sokli basin and evaluate whether these new data agree with the relative chronology, based on litho- and biostratigraphy, and support the earlier made land-sea correlation (Helmens et al., 2000).

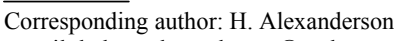

e-mail: helena.alexanderson@umb.no

ISSN 1897-1695 (online), 1733-8387 (print) (C) 2008 GADAM Centre, Institute of Physics, Silesian University of Technology.

All rights reserved. 


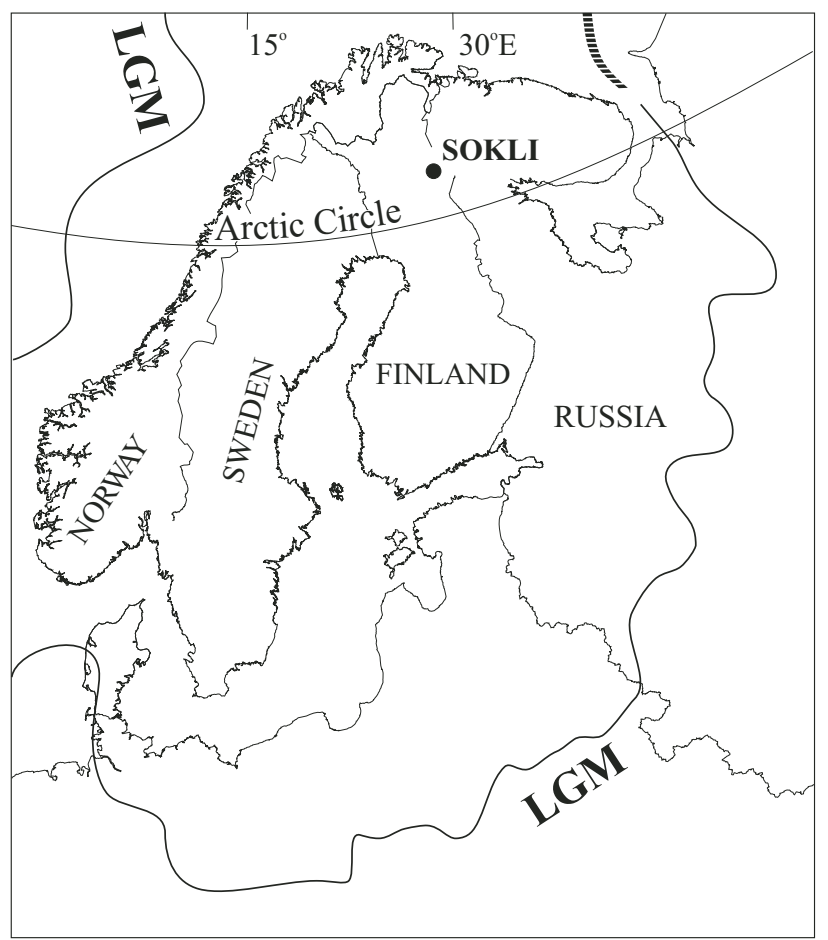

Fig. 1. Map of Fennoscandia with the Sokli Basin in eastern-central Finnish Lapland. The last glacial maximum (LGM) limit of the Fennoscandian ice sheet is from Svendsen et al. (2004).

\section{BACKGROUND}

\section{The Sokli sequence}

The Sokli sequence consists of fossil-rich mostly lacustrine sediments that alternate with a series of glacialdeglacial sequences consisting of till overlain by icemarginal fluvial sediments. A thick fluvial deposit with a large contribution of slope material occurs intercalated near the base of the sequence. Studies carried out by Helmens et al. $(2000 ; 2007 \mathrm{a})$ indicate that the non-glacial sediment beds in the Sokli sequence each have a characteristic lithological and palynological content. Thus, they represent successive developments, specific to each bed, both in terms of depositional and vegetational change. In other words, the sediments are not the result of redeposition, but occur in-situ, which is a very important conclusion to be drawn for a site which was repeatedly glaciated during the last glacial by the Fennoscandian ice sheet.

The unique sediment preservation in the Sokli basin is ascribed to specific conditions at the base of the Fennoscandian ice sheet in combination with atypical bedrock conditions. Glacial erosion in the region was limited due to low ice-velocities under the ice-divide zone of the ice sheet and/or to frozen bed conditions (Kleman et al., 1999; Boulton et al., 2001). Local bedrock conditions offered additional protection for the sediments against erosion since the sediments are situated in a deep depression in the relatively soft, deeply weathered and fractured rocks of the central Sokli Carbonatite Massif (Vartiainen, 1980), a carbonate-rich magma intrusion of very limited extent. The depression may have formed through weath- ering or by glacial carving during the Penultimate Glacial when the ice-divide zone was situated over northernmost Lapland (Hirvas, 1991).

A lithological column of borehole Sokli B-series cored in the central Sokli basin in 2002 is presented in Fig. 2. An interpretation in terms of former depositional environments and of main vegetation types (based on palynological analyses of parallel boreholes; Helmens et al. 2000; 2007a) is indicated directly to the right of the column, as is the Late Quaternary climate-stratigraphy.

\section{Optical dating}

Optically stimulated luminescence dating (OSL), or optical dating, has over the last few years developed considerably (Murray and Olley, 2002; Duller, 2004; Lian and Roberts, 2006) and is now used to date Late Quaternary environmental histories in various parts of the world (e.g. Spencer and Owen, 2004; Svendsen et al., 2004; Adrielsson and Alexanderson, 2005; Preusser et al., 2005).

Two basic requirements for optical dating to work are that the sediments contain quartz or feldspar and that they were bleached, or zeroed, by sunlight or heat at the event to be dated. The mineralogical prerequisite is usually not a problem since quartz and feldspar are among the most common minerals. Bleaching, on the other hand, is highly dependent on the setting and mode in which the sediment was deposited. If the sediment was not completely zeroed, for example if the sediment was briefly or partially exposed to sunlight, the resulting OSL age will overestimate the true age since the grains partly or wholly retain some older signal from the previous period of burial. This problem with incomplete bleaching is most relevant for environments with short transport distances and turbid transport media, a typical example being glacial environments. Grains from aeolian, littoral and some fluvial settings are less likely to be partially bleached. If partial bleaching is suspected there are several methods to, at least in part, overcome it, such as measuring single grains or small aliquots (Duller, 2006; Wallinga, 2002) or using linear modulation to resolve individual decay components (LM-OSL; Singarayer et al., 2005).

In the present study, lithology and sampling circumstances placed restrictions on our analyses. Sediments that were likely to have been reasonably well bleached at deposition, e.g. interstadial fluvial and glaciofluvial sediments, make up only a fraction of the total sequence. In addition, the retrieved core is only four $\mathrm{cm}$ in diameter. As a result of these restrictions, the amount of available material was very small. This severely limited the type and amount of measurements we could perform on each sample.

\section{METHODS}

\section{Sampling and description of the sediments}

The Sokli B-series borehole was collected in the winter of 2002 by means of a hydraulic piston corer. Cores were taken into a PVC tube, $2 \mathrm{~m}$ long and $4 \mathrm{~cm}$ in diameter, which was driven by vibration into the sediment while inserted in a steel tube. The PVC tubes were cut in 


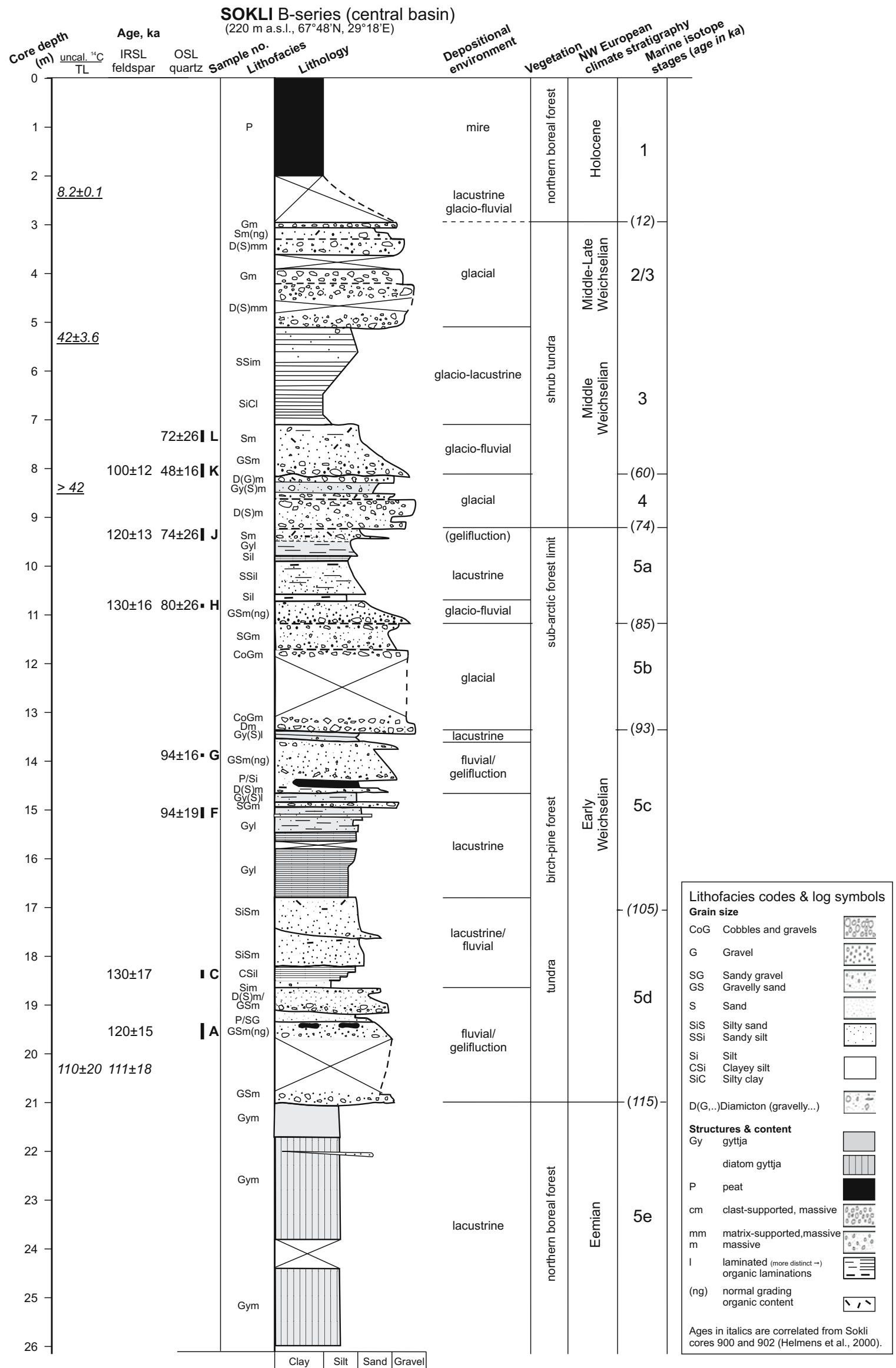

Fig. 2. Lithology of the Sokli B-series borehole from the Central Sokli Basin. A first interpretation in terms of former depositional environments and vegetation is indicated directly to the right of the lithological column. The absolute age control and the correlation with the NW European mainland climate-stratigraphy and marine oxygen-isotope stratigraphy, as indicated at the right side of the figure, are discussed in the text. Ages for the marine isotope stages are according to Martinson et al. (1987). 
halves under subdued light in the laboratory, where one side was used for lithological examination and selection of sample intervals for OSL dating. The other side of the core was directly wrapped in dark plastic and sent to the Dating Laboratory of the University of Helsinki for dating analyses.

Subsamples for OSL analyses were collected under subdued light conditions from the central, undisturbed parts of the core tubes, while subsamples for dose-rate measurements were taken from the sides of the tubes. The samples were sieved and for technical reasons the grainsize fraction 210-297 $\mu \mathrm{m}$ (fine medium sand) was chosen for further treatment. Heavy-liquid density separation was used to isolate quartz and potassium feldspar, the chosen densities were $2.62 \mathrm{~kg} / 1$ to separate quartz from feldspar and $2.58 \mathrm{~kg} / 1$ for separating $\mathrm{Na}$ - from $\mathrm{K}$-feldspar. After separation, both quartz and K-feldspar extracts were chemically treated to remove impurities. Quartz was treated with $40 \% \mathrm{HF}$ for one hour, followed by $10 \% \mathrm{HCl}$ for 30 minutes. For feldspar, the treatment was $10 \% \mathrm{HF}$ for 40 minutes and $10 \% \mathrm{HCl}$ for 10 minutes.

The sample lithology and the interpreted depositional environments together with relative chronological information are given in Table 1, see also the lithological column in Fig. 2. No suitable material for OSL dating was obtained from samples B, D, E and I (organic material or inadequate grain sizes).

\section{Dose-rate measurements}

One of the two factors needed to calculate the age in optical dating is the dose rate, i.e. the background radiation (mainly gamma and beta radiation), per unit of time, from natural radioactive elements in the soil and from cosmic radiation. In this study, beta dose rates were measured from the untreated sample material with a Risø
GM-25-5 beta multicounter (Bøtter-Jensen and Mejdahl, 1988). The conversion of the measured beta dose rate to absorbed dose is based on fitting the measurements to values from a set of reference samples of Finnish soil with known $\mathrm{U}$, Th and $\mathrm{K}$ content as determined by neutron activation (University of Helsinki Dating Laboratory, unpublished data). The conversion includes correction for grain size with the assumption that the measured material is dry. Alpha dose rates are not included because all alpha-dosed material has been etched away during $\mathrm{HF}$ treatment.

There was no possibility to make 'in situ' gamma dose rate measurements from the boreholes and the limited amount of sample material precluded gamma rate measurements in the laboratory after the samples were collected. The gamma dose rate was instead estimated from the gamma/beta relationship in the same series of measurements that was used for the conversion of the beta dose rate to absorbed dose determinations. This type of calculation results in slightly larger error margins than conventional, direct gamma measurements but conversion from beta counting has been shown to give a good prediction of total dose rate (Ankjærgaard and Murray 2007). The beta and gamma rates of dry sample material are listed in Table 2.

The water content of the samples (Table 2) was measured in the laboratory by weighing material, from the side of the tube, after it was saturated with water and again after drying. Coring conditions, e.g. pressure changes, prevented any 'in situ' or actual water content measurements. We believe that the sediments at the site have been saturated since they were deposited because the site is situated in a depression where there today is a peatland, and in the past repeatedly was a lake, and the sampled sediments are all taken below the average groundwater table. We also assume that any major com-

Table 1. Sample information and interpretation of the depositional environment based on sedimentological characteristics, see Fig. 2. The analysed minerals are quartz $(Q)$ and potassium feldspar $(F)$. Relative chronological information, from existing litho- and biostratigraphical data from the Sokli site (Helmens et al., 2000), is presented for groups of samples that belong to the same climate-stratigraphic unit.

\begin{tabular}{|c|c|c|c|c|c|}
\hline Sample no. & Sample depth & Mineral & Lithology & $\begin{array}{l}\text { Depositional } \\
\text { environment }\end{array}$ & Relative chronology \\
\hline L & $7.45-7.20$ & Q & $\begin{array}{l}\text { organic-rich sand with gravel inter- } \\
\text { layered with sandy (organic-rich) silt }\end{array}$ & $\begin{array}{l}\text { glaciofluvial (or glacio- } \\
\text { lacustrine) }\end{array}$ & \multirow{2}{*}{$\begin{array}{l}\text { Youngest. Older than the } \\
\text { topmost till and younger than } \\
\text { a lower till. }\end{array}$} \\
\hline K & 8.17-7.89 & Q & $\begin{array}{l}\text { diamict fining up to sandy fine gravel, } \\
\text { overlain by organic-rich sand with } \\
\text { gravel }\end{array}$ & glaciofluvial & \\
\hline $\mathrm{J}$ & $9.47-9.22$ & $Q, F$ & $\begin{array}{l}\text { gyttja interlayered with organic-rich } \\
\text { sand and gravel grading into lami- } \\
\text { nated organic sand }\end{array}$ & $\begin{array}{lcc}\text { lacustrine } & \text { with } & \text { fluvial } \\
\text { influence } & \text { (and } & \text { slope } \\
\text { material) } & & \\
\end{array}$ & \multirow{2}{*}{$\begin{array}{l}\text { Separated in time from } K \& L \\
\text { and } F \& G \text {, respectively, by } \\
\text { the duration of a stadial with } \\
\text { ice advancing and retreating } \\
\text { over the site. }\end{array}$} \\
\hline $\mathrm{H}$ & $10.85-10.72$ & $Q, F$ & sand with gravel fining up to fine sand & glaciofluvial & \\
\hline $\bar{G}$ & $13.87-13.85$ & $Q, F$ & well-sorted fine sand & fluvial (or aeolian?) & \multirow{2}{*}{$\begin{array}{l}\text { Some time after interglacial } \\
\text { and prior to the first }{ }^{*} \text { ice } \\
\text { covering the area. }\end{array}$} \\
\hline $\mathrm{F}$ & $15.16-14.95$ & Q & $\begin{array}{l}\text { sandy gyttja interlayered with sand } \\
\text { and wood }\end{array}$ & $\begin{array}{l}\text { lacustrine with fluvial } \\
\text { influence }\end{array}$ & \\
\hline C & $18.48-18.28$ & $\mathrm{~F}$ & laminated sandy silt & fluvial or lacustrine & \multirow[b]{2}{*}{ Oldest. Just after interglacial. } \\
\hline A & $19.70-19.35$ & $\mathrm{~F}$ & $\begin{array}{l}\text { gravelly coarse sand fining up to } \\
\text { sand }\end{array}$ & $\begin{array}{l}\text { fluvial with contribution } \\
\text { of slope material }\end{array}$ & \\
\hline
\end{tabular}

* recorded at this site 
paction which may have reduced the water content occurred early in the samples' history, thus not significantly changing the average water content over time. Thus, we use the saturated water content as the most appropriate approximation of the average water content since time of deposition (see also 5).

The beta and gamma dose rate values for dry material, $\mathrm{D}_{\beta \text {,dry }}$ and $\mathrm{D}_{\gamma, \text { dry }}$, were converted to wet-condition beta and gamma dose rates, $\mathrm{D}_{\beta}$ and $\mathrm{D}_{\gamma}$, using the equations of Aitken (1985):

$$
\begin{aligned}
& D_{\beta}=D_{\beta, d r y} /(1+1.25 W F) \text { and } \\
& D_{\gamma}=D_{\gamma, d r y} /\left(1+1.14 W_{1} F\right)
\end{aligned}
$$

where $W$ is the saturated water content of the sample expressed as weight of the water/dry weight, see Table 2. $W_{1}$ is the water content factor for the soil material in which the sample was situated, in this case we consider $W_{1}$ to be the same as $W . F$ is a factor that indicates how close to saturation level the water content has been since the time of deposition. An uncertainty factor $\delta F$ can be added to $F$ and in our case, since we believe the water content to have been close to saturation throughout, we use $F \pm \delta F=0.9 \pm 0.1$.

Most samples are situated away from abrupt lithological changes and we assume that the gamma dose rate does not change dramatically close to the sample and that the calculated dose rate (Table 2) is representative for the surrounding sediments. Due to the large uncertainties in the determination of the dose rate the overall uncertainty must nevertheless be put as high as $12 \%$, derived from error propagation and best estimates of uncertainties in the beta/gamma-relation and water contents.

Due to a generally very small amount of K-feldspar left in the samples after separation and purification, the potassium content and thereby the internal beta dose rate of K-feldspar could only be measured on one sample (A; K-content 9.9\%) using a Risø GM-25-5 beta multicounter.

\section{Dose measurements}

The other factor in the optical dating age equation is the equivalent dose, i.e. the estimate of the amount of radiation a grain has been exposed to since it was last

Table 2. Measured beta and gamma dose rates for dry and wet (saturated) sample material. The saturated water content is stated, but estimated only for samples $A$ and $C$. An uncertainty of $\pm 8 \%$ has been used for the total dose rate, which is based on the saturated water content.

\begin{tabular}{lcccccc}
\hline & \multicolumn{2}{c}{ Dry } & \multicolumn{2}{c}{ Wet } & Total \\
\cline { 2 - 7 } Sample & $\begin{array}{c}\text { Beta } \\
\text { (Gy/ka) }\end{array}$ & $\begin{array}{c}\text { Gamma } \\
\text { (Gy/ka) }\end{array}$ & $\begin{array}{c}\text { Beta } \\
\text { (Gy/ka) }\end{array}$ & $\begin{array}{c}\text { Gamma } \\
\text { (Gy/ka) }\end{array}$ & $\begin{array}{c}\text { Water } \\
\text { content } \\
\text { (mass\%) }\end{array}$ & $\begin{array}{c}\text { Dose rate } \\
\text { (Gy/ka) }\end{array}$ \\
\hline L & 3.1 & 0.99 & 2.1 & 0.70 & 39.5 & $2.8 \pm 0.23$ \\
K & 2.6 & 1.1 & 2.1 & 0.89 & 18.1 & $3.0 \pm 0.24$ \\
J & 1.8 & 0.96 & 1.3 & 0.73 & 30.6 & $2.0 \pm 0.16$ \\
H & 1.6 & 0.91 & 1.2 & 0.73 & 23.9 & $2.0 \pm 0.16$ \\
G & 1.6 & 0.92 & 1.3 & 0.75 & 21.5 & $2.0 \pm 0.16$ \\
F & 2.5 & 1.1 & 1.5 & 0.68 & 52.7 & $2.2 \pm 0.18$ \\
C & 2.5 & 1.2 & 2.0 & 0.94 & $\sim 20$ & $2.9 \pm 0.24$ \\
A & 2.6 & 1.2 & 2.0 & 0.96 & $\sim 20$ & $3.0 \pm 0.24$ \\
\hline
\end{tabular}

bleached. Here, the dose measurements of the purified quartz and feldspar samples were done according to a single aliquot regeneration (SAR) protocol (Murray and Wintle, 2000), see Table 3. Infrared light (830 $\Delta 10 \mathrm{~nm})$ was used to stimulate the feldspars and blue LEDs (420-550 nm) for the quartz. Three different regeneration doses were given to determine the relationship between absorbed dose and the intensity of the OSL-signal. The regeneration doses were chosen for each sample so that $\mathrm{D}_{1}$ was smaller than the natural dose, $\mathrm{D}_{3}$ higher and $\mathrm{D}_{2}$ about the same as the natural dose. Constant test doses after each regeneration cycle compensated for any sensitivity changes in the OSL-signal. Preheat experiments showed that temperatures above $260^{\circ} \mathrm{C}$ had to be used so we adopted a preheat temperature of $280^{\circ} \mathrm{C}$, while cut heat temperature was $160^{\circ} \mathrm{C}$. Although tests for thermal transfer were not carried out in this study, Alexanderson et al. (2008) have shown thermal transfer to be nonexistent or negligible for similar types of sediments in Sweden. Individual aliquots with recycling ratios $<0.9$ or $>1.1$ were discarded.

The measurements were made on aliquots containing approximately 1000 grains in cups. Large aliquots were needed to get a good luminescence signal since tests with single-grain analyses showed that only very few grains were bright. Due to small amounts of material only a few (4-12) aliquots could be measured for most samples. The OSL-measurements were made with an upgraded Risø TL-DA-12 reader (Bøtter-Jensen and Duller, 1992; Bøtter-Jensen et al., 1999). The OSL signal was derived by integrating the whole peak (number of channels adapted to different shine-down times for different samples) and subtracting the background level (channels 240-250), see Fig. 3a.

\section{RESULTS}

\section{Sample and OSL signal characteristics}

The saturated water content of the samples was between 18 and 53\% (Table 2) and is considered to be similar to the average water content since time of deposition (see 3). Samples F and J have high organic content (gyttja, Table 1; loss of ignition 6-13\%, K.F. Helmens, unpublished data).

Table 3. The single aliquot regeneration (SAR) protocol used for measurements.

\begin{tabular}{rlrl}
\hline Step & Action & Step & Action \\
\hline & & 6 & Give regeneration dose \\
& $D_{n}$ \\
1 & Preheat $^{*}, 280^{\circ} \mathrm{C}$ & 7 & Preheat $^{*}, 280^{\circ} \mathrm{C}$ \\
2 & Measure natural & 8 & Measure regenerated \\
& OSL & & OSL \\
3 & Give test dose $\mathrm{D}_{T}$ & 9 & Give test dose $\mathrm{D}_{\mathrm{T}}$ \\
4 & Cutheat $^{*}, 160^{\circ} \mathrm{C}$ & 10 & Cutheat $^{*}, 160^{\circ} \mathrm{C}$ \\
5 & Measure test OSL & 11 & Measure test OSL \\
& & Steps 6 to 11 are re- \\
peated four times with $\mathrm{D}_{\mathrm{n}}$ \\
& $=\mathrm{D}_{1}, \mathrm{D}_{2}, \mathrm{D}_{3}$ and $\mathrm{D}_{1}$. \\
\hline
\end{tabular}

*With 10 s pause. 
The OSL signals from the quartz grains were generally not very bright, especially so for sample L, and the peak intensity varied significantly between samples but generally it was fairly low (Fig. 3a). The natural luminescence values intersected the linear part of the growth curves for most samples but some aliquots seemed close to saturation (Fig. 3b). Recycling ratios are generally good (within $10 \%$ of unity). Very low IR/blue ratios
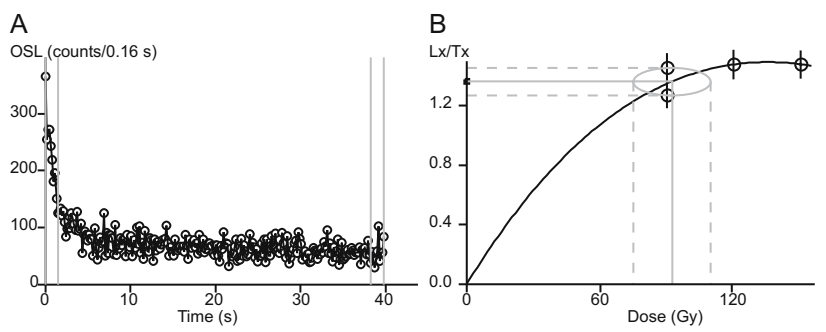

Fig. 3. This shine-down curve $(A)$ and growth curve $(B)$ from an aliquot from sample $J$ (quartz) illustrate some of the problematic characteristics of some of the Sokli OSL-samples. The signal strength is weak due to $\operatorname{dim}$ quartz (A) and the natural OSL ( $(\mathrm{n} / \mathrm{Tn})$ intercepts the growth curve close to saturation $(B)$. Both these factors contribute to the large uncertainty of the dose estimates. The channels used for peak and background calculation are indicated with grey lines in $A$ and the hatched lines in $B$ represent the errors of the $L n / T n$ measurement and the dose estimate.
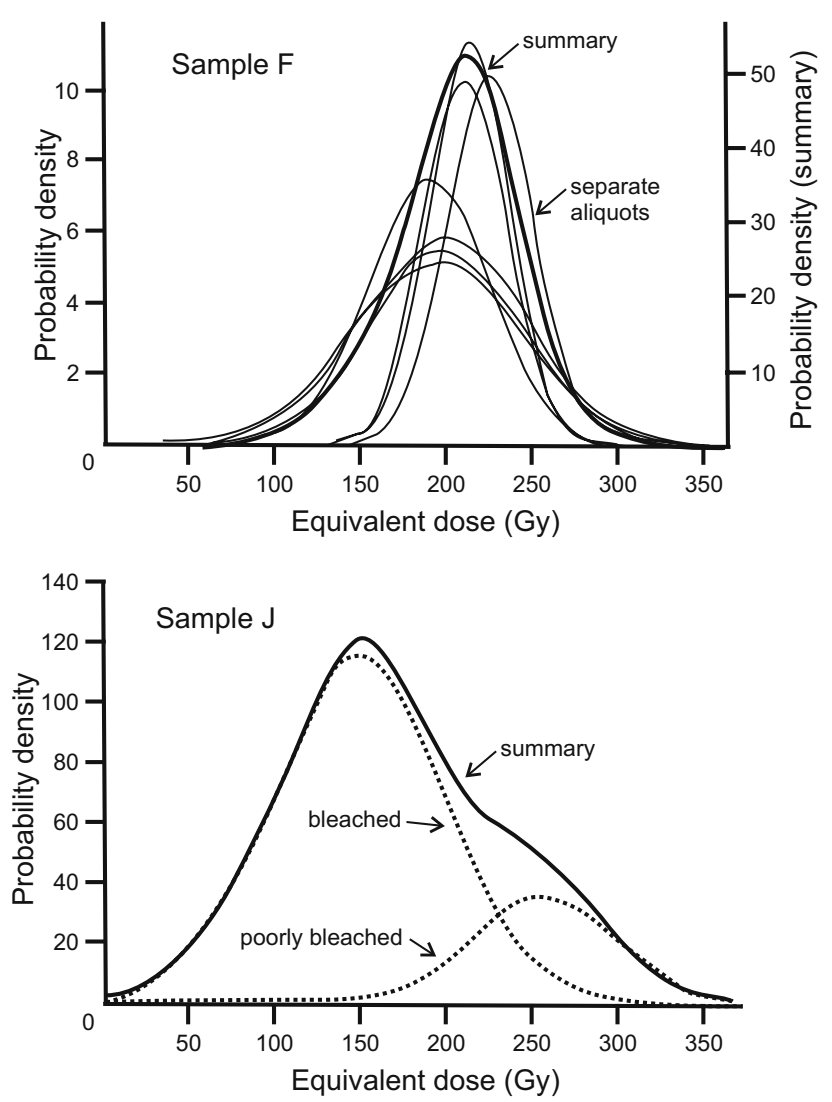

Fig. 4. Normalized Gaussian probability dose distributions of all aliquots of quartz sample $F$, which is considered well-bleached, and of quartz sample $\mathrm{J}$, which is considered poorly bleached. The lower figure also shows a summary curve for all aliquots and the two dose populations of sample J, one well-bleached and one which contains poorly bleached grains. show that the quartz samples are not contaminated by feldspar (Duller, 2003). The IRSL signals from the $\mathrm{K}$-feldspar aliquots were, on the other hand, quite strong.

\section{Equivalent doses and ages}

The equivalent doses from quartz, which were calculated as the weighted averages of the dose distributions from the aliquots, are listed in Table 4 together with the resulting ages. The dose distributions are generally quite broad but are for most samples symmetrical (Fig. 4). One exception is sample $\mathrm{J}$, which has a tail of high doses and thus seems to contain two populations of grains, the older one being close to saturation. Only the younger population was used to calculate the final age. The K-feldspar IRSL measurements also resulted in broad distributions of doses.

\section{DISCUSSION}

\section{Samples and signals}

The sampling technique (i.e. coring) placed some inherent limitations on the samples, most specifically small amounts of material to work with and increased uncertainty of dose-rate calculations (see 2). These limitations and sources of uncertainty, further discussed below, have led to large standard errors for the final ages.

The inaccuracy in dose-rate estimation is a large contributor to the large uncertainties. This is caused partly by technical limitations (i.e. equipment access), which we hope to remedy in future investigations, and partly by the difficulty in estimating average water content. The range of saturated water content that has been measured reflects the variation in grain size and organic content of the sampled sediments. To see the effect of variations in water content, for example due to compaction, ages were also calculated with water contents equal to typical porosity values for the respective grain sizes (Knutsson and Morfeldt, 1993). The porosity values are higher than the saturated water content for all samples, but final ages do not change significantly except for sample F. Sample F is a gyttja, which can have a very high water content, and its age thus becomes considerably older $(\sim 125 \pm 20 \mathrm{ka}$ if

Table 4. Summary table of equivalent doses, dose rates and ages ( \pm one standard error). The samples are listed in stratigraphic order from top to bottom. Feldspar ages are corrected for K-content but not for fading. Q - quartz, F-feldspar.

\begin{tabular}{rcccrr}
\hline $\begin{array}{c}\text { Sample } \\
\text { ral }\end{array}$ & $\begin{array}{c}\text { Equivalent } \\
\text { dose (Gy) }\end{array}$ & $\begin{array}{c}\text { Dose rate } \\
\text { (Gy/ka) }\end{array}$ & \multicolumn{1}{c}{$\begin{array}{c}\text { Age } \\
\text { (ka) }\end{array}$} & n \\
\hline L & Q & $200 \pm 71$ & $2.8 \pm 0.23$ & $72 \pm 26$ & 9 \\
K & Q & $140 \pm 46$ & $3.0 \pm 0.24$ & $48 \pm 16$ & 7 \\
K & F & $450 \pm 39$ & $4.5 \pm 0.36$ & $100 \pm 12$ & 4 \\
J & Q & $150 \pm 50$ & $2.0 \pm 0.16$ & $74 \pm 26$ & 28 \\
J & F & $370 \pm 27$ & $3.1 \pm 0.24$ & $120 \pm 13$ & 6 \\
H & Q & $160 \pm 47$ & $2.0 \pm 0.16$ & $80 \pm 26$ & 12 \\
H & F & $360 \pm 36$ & $2.9 \pm 0.23$ & $130 \pm 16$ & 4 \\
G & Q & $190 \pm 17$ & $2.0 \pm 0.16$ & $94 \pm 16$ & 5 \\
F & Q & $210 \pm 35$ & $2.2 \pm 0.18$ & $94 \pm 19$ & 7 \\
C & F & $570 \pm 61$ & $4.4 \pm 0.35$ & $130 \pm 17$ & 4 \\
A & F & $540 \pm 51$ & $4.5 \pm 0.36$ & $120 \pm 15$ & 6 \\
\hline
\end{tabular}


w.c. $=100 \%$ ). This does, however, not change the geological interpretation since sample $\mathrm{F}$ is below the first evidence of glaciation at the site.

Another factor that contributes to the large errors is the width of the dose distributions. For the quartz samples the broad dose distributions are largely due to weak OSL signals which bring uncertainty to the separate measurements, and for some aliquots, partly also due to the intersect of the natural OSL with the upper part of the growth curve. Very small feldspar samples in combination with differing K-contents/internal beta rates led to wide dose distributions for feldspar samples. The reliability of the IRSL-measurements of K-feldspar is also affected by the possibility of anomalous fading and longer bleaching times compared to quartz. No fading measurements could be made in this study, so the feldspar ages must be used with caution. However, investigations by Meisl and Huntley (2005) and Visocekas (2000) suggest that the fading effect of Finnish feldspar may be small. Incomplete bleaching (see below) may have a larger effect.

Broad distributions may also reflect populations of grains bleached to different degrees, i.e. that not all grains have been completely zeroed. The sediments we sampled were, according to palaeoecological and lithological investigations, deposited in periglacial environments characterized by open vegetation, active soil movement and highly seasonal water flows (Helmens et al., 2000; 2007a). Investigations of fluvial and glaciofluvial sediments from similar settings in present day Arctic shows that in summertime zeroing is basically complete in less than $\sim 2 \mathrm{~km}$, and that a residual of, in this context, only $\sim 500$ years may remain during rapid springflood deposition (Alexanderson, 2007). At Sokli, sediments have likely been transported several kilometres (estimated distances $<20 \mathrm{~km}$ ) and should thus have been exposed to enough sunlight to reduce the OSL signal to zero.

\section{OSL ages and stratigraphy}

Apart from sample L (discussed below), the quartz ages follow stratigraphic order with the youngest on top and successively older with depth (Fig. 2) and thus agree with the relative chronology of the sequence (Tables 1 and 4). The feldspar ages are, on the other hand, more or less the same throughout the succession. Since quartz is more quickly and easily zeroed than feldspar (GodfreySmith et al., 1988; Fuchs et al., 2005), a considerable difference between quartz and feldspar OSL ages can be used as an indication of incomplete bleaching (Hansen et al., 1999). For the three samples (H, J, K) where both types of measurements have been done, the feldspar OSL age is significantly higher ( $\sim 50 \mathrm{ka})$ than the quartz OSL age. This suggests that bleaching conditions were not optimal - the feldspar grains were not completely bleached - and that the quartz OSL age is more likely to be correct. The two age populations of grains in sample $\mathrm{J}$ (Fig. 4) is also an indication of relatively poor bleaching conditions, despite fairly long estimated transport distances.

Samples K and L are from one and the same sedimentological unit but their quartz OSL ages differ by $\sim 25 \mathrm{ka}$ and the order is inverted. Between this unit and samples $\mathrm{H}$ and $\mathrm{J}$ are stadial sediments that infer the presence of an ice sheet, which suggests that samples $\mathrm{K}$ and $\mathrm{L}$ should be significantly younger than $\sim 74-80 \mathrm{ka}$ (Table 1). The younger of the two ages (48 ka) thus seems to be the more likely one. The sediments of sample L display signs of increased lacustrine influence compared to those of sample K, which may explain reduced sunlight exposure and subsequent incomplete bleaching. The OSL characteristics of sample L were also very poor and the results from that sample are considered less reliable.

Since the standard errors are so large the four samples $\mathrm{F}, \mathrm{G}, \mathrm{H}$ and $\mathrm{J}$ are strictly indistinguishable. Based on palynological and sedimentological information (Helmens et al., 2007a) it is nevertheless evident that samples $\mathrm{F}$ and $\mathrm{G}$ belong to another stratigraphical unit and another interstadial than samples $\mathrm{H}$ and J (Fig. 2, Table 1). The age difference indicated by the mean values (94 ka vs $80-74 \mathrm{ka}$ ) is therefore likely to be true. That the two samples $F$ and $G$, which are both from the upper part of the same climatestratigraphic unit (Helmens et al., 2007a), have the same age (94 ka) also supports the accuracy of this result.

The oldest samples A and C have only feldspar ages (120-130 ka). If incomplete bleaching were of the same order $(50 \mathrm{ka})$ as for samples $\mathrm{H}, \mathrm{J}$ and $\mathrm{K}$ the true age would be 70-80 ka, younger than the overlying sediments (samples $\mathrm{G}$ and $\mathrm{F}$ ) and thus stratigraphically inconsistent. It is therefore likely that these samples suffer less, if at all, from incomplete bleaching. This is accordance with Hansen et al. (1999) who noted that incomplete bleaching seemed to be less of a problem during glacial build-up than during glacial decay and deglaciation, when deposition generally took place more rapidly.

\section{Correlation with the deep-sea record}

The bio- and lithostratigraphical data from Sokli allow a correlation with the well-dated marine isotope record (Helmens et al., 2007a): the sequence shows progressively colder conditions for both the warm and cold stages of the Weichselian as each period evolves. If taken at face value, the quartz OSL ages support this correlation.

The age of the youngest sample, sample K (48 ka), places it in MIS 3 ( 59-24 ka). This is also confirmed by an AMS radiocarbon dating on wood in the overlying lacustrine sediments, correlated from another core (Fig. 2). The wood is dated to $42,450 \pm 3570{ }^{14} \mathrm{C}$ yr BP (Helmens et al., 2000). This age is accepted as a finite age, although close to the limit of the radiocarbon dating method. Recently, an AMS radiocarbon age of 54,000 +/$7000 / 4000{ }^{14} \mathrm{C}$-yr BP has been obtained on mostly terrestrial macrofossils from the Sokli B-series borehole, from the same interval as the wood sample (Helmens et al., 2007b). The differences in radiocarbon ages are most probably related to uncertainties near the limit of the radiocarbon dating method. Both our OSL data and the two radiocarbon dates suggest an early MIS 3 age.

Samples F and G (94 ka) correspond to marine oxygen isotope (MIS) stage 5c ( 105-93 ka; Martinson et al., 1987), while samples H and J (80-74 ka) fall into MIS 5a ( 85-74 ka). The feldspar IRSL ages of the oldest samples A and C (120-130 ka) are slightly older than the correlated oxygen isotope stage $(5 \mathrm{~d} ; 105-115 \mathrm{ka})$ but not 
as far off as the other feldspar samples. This supports the idea of better bleaching conditions during this stage, which follows the Eemian interglacial, than during later stages, which follow periods of glaciation (see above). The ages are also similar, within errors, to TL and IRSL ages from the same units in another core from Sokli (Helmens et al., 2000; Fig. 2).

\section{Dating Weichselian interstadials}

There are rather few reliable absolute dates of Early and Middle Weichselian events in the central area of Fennoscandian glaciation. This is both due to the fragmented nature of preserved deposits and, until fairly recently, a lack of absolute dating techniques with a sufficient age range and precision. Age control for tillcovered non-glacial sediments in Fennoscandia has mostly been based on correlation with the NW European mainland biostratigraphy and deep-sea oxygen-isotope stages. This correlation has been fraught with uncertainties (Donner, 1996): interstadial sediments are usually not found in sequence with Eemian sediments (i.e. the interstadial sediment could belong to an older cold stage than the Weichselian); sediment beds are mostly truncated, covering only part of an interstadial (or interglacial) sequence; the distance of correlation is large (including an area with a great range of climatic conditions due to differences in latitude and altitude); and as the differences in vegetational history between the Early Weichselian interstadials on the mainland are very small, correlation is almost impossible. As such, many uncertainties exist in the Weichselian histories that have been constructed based on the sedimentary record.

Compared to radiocarbon dating, luminescence dating has the advantages of a greater age range (covers the entire Weichselian) and the ability to date minerogenic material. A number of interstadial sites in Fennoscandia have been dated by thermoluminescence (TL) and, over the last few years, by optically stimulated luminescence (e.g. Garcia Ambrosiani, 1991; Olsen, 1996; Påsse, 1998; Mäkinen, 2005; Lagerbäck, 2007; Alexanderson et al., 2008). The experiences show that the interpretation of the results is not always straightforward. Inconsistent results may be due to site factors (e.g. poor stratigraphic control, difficulty to assess water content) or to the luminescence properties of a sample (incomplete bleaching, weak signals, etc.). Detailed descriptions of sites and sample properties are therefore important to help judge the quality of results.

\section{CONCLUSIONS}

Interstadial and non-glacial stadial sediments collected in boreholes from Sokli in northeastern Finland have been dated by optically stimulated luminescence on single aliquots of quartz and feldspar. Generally, the OSL ages have rather large standard errors mainly due to relatively poor luminescence characteristics, small sample sizes and uncertainties in dose-rate determinations. Some of these problems are expected to be reduced in future studies.
The quartz OSL ages follow stratigraphic order, with one exception, and agree well with the relative chronology based on lithostratigraphy and palynology, which strengthens their credibility. The youngest age also matches a radiocarbon age from the overlying unit. Thus, the ages support the litho- and biostratigraphical correlation with the NW European mainland climate stratigraphy and the marine oxygen isotope stages. However, although the ages indicate an Early to Middle Weichselian age for the dated sequence, the large uncertainties associated with the ages preclude a definite absolute dating. The feldspar IRSL dates generally overestimate the age with up to $50 \mathrm{ka}$, most likely due to incomplete bleaching.

The Sokli sequence represents an exceptional record for Fennoscandia as the sediment succession nearly continuously covers the last interglacial-glacial cycle. The combined chronological, palynological and sedimentological data from the Sokli core show that during the last glacial cycle northeastern Finland was not glaciated until MIS 5b, around $90 \mathrm{ka}$. Progressively colder interstadial intervals are dated to around $\sim 94 \mathrm{ka}$ (MIS 5c), 74-80 ka (MIS 5a) and 42-54 ka (MIS 3).

\section{ACKNOWLEDGEMENTS}

Karin Helmens has analysed the Sokli core lithologically and palynologically, and initiated and guided the dating program. Kari Eskola has prepared the samples and performed all OSL-analyses. Helena Alexanderson has contributed with inputs regarding Quaternary geology and optical dating and has done an important part of the writing. We are indebted to Dr. Högne Jungner (Dating Laboratory, University of Helsinki, Finland) for his interest and support of the dating program.

The coring at Sokli was performed and financed by the Geological Survey of Finland. We wish to thank the Arctic Centre (University of Lapland, Finland) for providing the logistic support to make detailed lithological descriptions of borehole Sokli B-series. We have also benefited from the anonymous reviewers' useful comments on the manuscript.

\section{REFERENCES}

Adrielsson L and Alexanderson H, 2005. Interactions between the Greenland Ice Sheet and the Liverpool Land coastal ice cap during the last two glaciation cycles. Journal of Quaternary Science 20(3): 269-283, DOI 10.1002/jqs.900.

Aitken MJ, 1985. Thermoluminescence dating. Academic Press, London: $359 \mathrm{pp}$.

Alexanderson H, 2007: Residual OSL signals from modern Greenlandic river sediments. Geochronometria 26: 1-9, DOI 10.2478/v10003007-0001-6.

Alexanderson H, Johnsen T, Wohlfarth B, Näslund J-O and Stroeven A, 2008: Applying the optically stimulated luminescence (OSL) technique to date the glacial history of southern Sweden. Reports from the Department of Physical Geography and Quaternary Geology, Stockholm University, no. 4.33 p.

Ankjærgaard C and Murray AS, 2007. Total beta and gamma dose rates in trapped charge dating based on beta counting. Radiation Measurements 42: 352-359, DOI10.1016/j.radmeas.2006.12.007.

Boulton GS, Dongelmans P, Punkari M and Broadgate M, 2001. Palaeoglaciology of an ice sheet through a glacial cycle: the European ice sheet through the Weichselian. Quaternary Science Reviews 20(4): 591-625, DOI 10.1016/S0277-3791(00)00160-8

Bøtter-Jensen L and Duller GAT, 1992. A new system for measuring optically stimulated luminescence from quartz samples. Nuclear 
Tracks and Radiation Measurements 20(4): 549-553, DOI 10.1016/1359-0189(92)90003-E

Bøtter-Jensen L and Mejdahl V, 1988. Assessment of beta dose-rate using a GM multicounter system. Nuclear Tracks and Radiation Measurements 14(1-2): 187-191, DOI 10.1016/13590189(88)90062-3.

Bøtter-Jensen L, Mejdahl V and Murray AS, 1999. New light on OSL. Quaternary Geochronology 18, 303-309, DOI 10.1016/S02773791(98)00063-8.

Donner J, 1996. The Early and Middle Weichselian interstadials in the central area of Scandinavian glaciations. Quaternary Science Reviews 15: 471-479, DOI 10.1016/0277-3791(96)00002-9.

Duller GAT, 2003. Distinguishing quartz and feldspar in single grain luminescence measurements. Radiation Measurements 37: 161165, DOI 10.1016/S1350-4487(02)00170-1.

Duller GAT, 2004. Luminescence dating of Quaternary sediments: recent advances. Journal of Quaternary Science 19(2): 183-192, DOI 10.1002/jqs. 809

Duller GAT, 2006. Single grain optical dating of glacigenic deposits. Quaternary Geochronology 1: 296-304, DOI 10.1016/j.quageo.2006.05.018.

Fuchs M, Straub J and Zöller L, 2005. Residual luminescence signals of recent river flood sediments: A comparison between quartz and feldspar of fine- and coarse-grain sediments. Ancient TL 23: 25-30.

Garcia Ambrosiani K, 1991. Interstadial minerogenic sediments at the Leveäniemi mine, Svappavaara, Swedish Lapland. Geologiska Föreningens i Stockholm Förhandlingar 113: 273-287.

Godfrey-Smith DI, Huntley DJ and Chen WH, 1988. Optical dating studies of quartz and feldspar sediment extracts. Quaternary Science Reviews 7: 373-380, DOI 10.1016/0277-3791(88)90032-7.

Hansen L, Funder S, Murray AS and Mejdahl V, 1999. Luminescence dating of the last Weichselian glacier advance in East Greenland. Quaternary Geochronology 18: 179-190, DOI 10.1016/S02773791(98)00051-1.

Helmens KF, Räsänen ME, Johansson PW, Jungner H and Korjonen K, 2000. The Last Interglacial-Glacial cycle in NE Fennoscandia: a nearly continuous record from Sokli (Finnish Lapland). Quaternary Science Reviews 19(16): 1605-1623, DOI 10.1016/S02773791(00)00004-4.

Helmens KF, Johansson PW, Räsänen ME, Alexanderson H and Eskola $\mathrm{KO}, 2007 \mathrm{a}$. Ice-free intervals at Sokli continuing into Marine Isotope Stage 3 in the central area of the Scandinavian glaciations. Bulletin of the Geological Society of Finland 79: 17-39.

Helmens KF, Bos JAA, Engels S, Van Meerbeeck CJ, Bohncke SJP, Renssen H, Heiri O, Brooks SJ, Seppä H, Birks HJB and Wohlfarth B. 2007b. Present-day temperatures in northern Scandinavia during the Last Glaciation. Geology 35: 987-990, DOI 10.1130/G23995A.1.

Hirvas H, 1991. Pleistocene stratigraphy of Finnish Lapland. Geological Survey of Finland, Bulletin 354: 123 p.

Kleman J, Hättestrand C and Clarhäll A, 1999. Zooming in on frozenbed patches: scale-dependent controls on Fennoscandian ice sheet basal thermal zonation. Annals of Glaciology 28: 189-194, DOI $10.3189 / 172756499781821670$

Knutsson $\mathrm{G}$ and Morfeldt CO, 1993. Grundvatten teori \& tillämpning (Groundwater theory \& application). Svensk Byggtjänst, Solna: 304 pp (in Swedish).
Lagerbäck R, 2007. Ventifacts - means to reconstruct glacial development and palaeo-environment in northern and central Sweden. GFF 129, 315-324.

Lian OB and Roberts RG, 2006. Dating the Quaternary: progress in luminescence dating of sediments. Quaternary Science Reviews 25: 2449-2468, DOI10.1016/j.quascirev.2005.11.013.

Martinson DG, Pisias NG, Hays JD, Imbrie J, Moore TC and Shackleton NJ, 1987. Age dating and the orbital theory of the ice ages: development of a high-resolution 0 to 300,000-year chronostratigraphy. Quaternary Research 27(1): 1-29, DOI 10.1016/00335894(87)90046-9.

Meisl NK and Huntley DJ, 2005. Anomalous fading and activation energies of feldspars. Ancient TL 23: 1-8.

Murray AS and Olley JM, 2002. Precision and accuracy in the optically stimulated luminescence dating of sedimentary quartz: a status review. Geochronometria 21: 1-16.

Murray AS and Wintle AG, 2000. Luminescence dating of quartz using an improved single aliquot regenerative-dose protocol. Radiation Measurements 32: 57-73, DOI 10.1016/S1350-4487(99)00253-X.

Mäkinen K, 2005: Dating the Weichselian deposits of south-western Finnish Lapland. Geological Survey of Finland, Special Paper 40: 67-78.

Olsen L, Mejdahl V and Selvik SF, 1996. Middle and Late Pleistocene Stratigraphy, chronology and glacial history in Finnmark, North Norway. Norges Geologiske Undersøkelse, Bulletin 429: 1-111.

Preusser F, Andersen BG, Denton GH and Schlüchter C, 2005. Luminescence chronology of Late Pleistocene glacial deposits in North Westland, New Zealand. Quaternary Science Reviews 24: $2207-$ 2227, DOI10.1016/j.quascirev.2004.12.005.

Påsse T, 1998: Early Weichselian interstadial deposits within the drumlins at Skrea and Vinberg, southwestern Sweden. GFF 120: 349356.

Singarayer JS, Bailey RM, Ward S and Stokes S, 2005. Assessing the completeness of optical resetting of quartz OSL in the natural environment. Radiation Measurements 40(1): 13-25, DOI 10.1016/j.radmeas.2005.02.005.

Spencer JQ and Owen LA, 2004. Optically stimulated luminescence dating of Late Quaternary glaciogenic sediments in the upper Hunza valley: validating the timing of glaciation and assessing dating methods. Quaternary Science Reviews 23: 175-191 DOI10.1016/S0277-3791(03)00220-8.

Svendsen JL, Alexanderson H, Astakhov VI, Demidov I, Dowdeswell JA, Funder S, Gataullin V, Henriksen M, Hjort C, HoumarkNielsen M, Hubberten HW, Ingólfsson Ó, Jakobsson M, Kjær KH, Larsen E, Lokrantz H, Lunkka JP, Lyså A, Mangerud J, Matioushkov A, Murray A, Möller P, Niessen F, Nikolskaya O, Polyak L, Saarnisto M, Siegert C, Siegert MJ, Spielhagen RF and Stein R, 2004. Late Quaternary ice sheet history of northern Eurasia. Quaternary Science Reviews 23(11-13): 1229-1271, DOI 10.1016/j.quascirev.2003.12.008.

Vartiainen $H, 1980$. The petrography, mineralogy and petrochemistry of the Sokli carbonatite massif, northern Finland. Geological Survey of Finland, Bulletin 313: 126 pp.

Visocekas R, 2000. Monitoring anomalous fading of TL of feldspars by using far-red emission as a gauge. Radiation Measurements 32: 499-504, DOI 10.1016/S1350-4487(00)00054-8.

Wallinga $J, 2002$. On the detection of OSL age overestimation using single-aliquot techniques. Geochronometria 21: 17-26. 